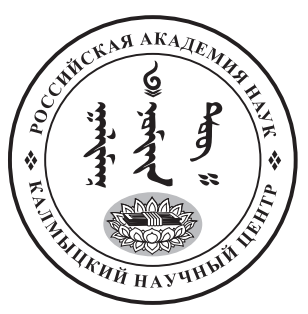

Published in the Russian Federation

Oriental Studies (Previous Name: Bulletin of the Kalmyk Institute

for Humanities of the Russian Academy of Sciences)

Has been issued as a journal since 2008

ISSN: 2619-0990; E-ISSN: 2619-1008

Vol. 14, Is. 3, pp. 568-580, 2021

Journal homepage: https://kigiran.elpub.ru

УДК / UDC 930.2

DOI: 10.22162/2619-0990-2021-55-3-568-580

\title{
Образ Шестирукого Махакалы и его окружения в тексте «Ритуал умилостивления и подношения торма Быстродействующему Защитнику Мудрости - Шестирукому Махакале»
}

Соелма Ринчиновна Батомункуева ${ }^{1}$

${ }^{1}$ Институт монголоведения, буддологии и тибетологии СО РАН (д. 6, ул. Сахьяновой, 670047 Улан-Удэ, Российская Федерация)

кандидат философских наук, младший научный сотрудник

iD) 0000-0002-5060-0296. E-mail: soelmul@mail.ru

(C) КалмНЦ РАН, 2021

(C) Батомункуева С. Р., 2021

Аннотация. Введение. Данная статья представляет собой исследование ритуального текста, посвященного Шестирукому Махакале. Махакала является одним из главных защитников тибетского буддизма. В статье дается описание Шестирукого Махакалы и его основного окружения, представлена структура текста, раскрывающая его содержание и показывающая правила и последовательность действий почитания божества. Отмечается компилятивный характер текста, а также выделены персоналии, работы которых легли в основу ритуального текста под общим авторством Кхедрупа Чже. Исследуемый текст является одним из наиболее обширных, включающим в себя множество других сопутствующих ритуалов. Целью работы является передача и интерпретация образа и атрибутов Шестирукого Махакалы на основе переведенного фрагментатекстаи введениеегов научныйоборот. Материаломдля исследования послужил текст «Ритуал умилостивления...». Методы. В статье использован описательный метод, а также методы структурно-семантического, концептуального и контекстуального анализа. Результаты. Иконография Шестирукого Махакалы, представленная в тексте, развернуто описывает божество с детальным разъяснением некоторых его элементов. Все это позволяет раскрыть гневную природу грозного дхармапалы и показать, что все элементы атрибуты, одеяния, украшения, позы, жесты - имеют глубокое символическое значение, связанное с философскими и религиозными идеями, а также этическими нормами буддизма. Предварительное ознакомление, структурирование и анализ части текста показывают верность и необходимость изучения и введения в научный оборот ритуальных текстов как вспомогательных источников по исследованию культов буддийских божеств.

Ключевые слова: буддизм, буддийский пантеон, Махакала, дхармапала, буддийские тексты, буддийский ритуал 
Благодарность. Работа выполнена в рамках государственной субсидии — проект «Памятники письменности народов России и Внутренней Азии на восточных языках и архивные документы XVIII - нач. XXI вв. в контексте межцивилизационного взаимодействия» (номер госрегистрации: № 121031000302-9).

Для цитирования: Батомункуева С. Р. Образ Шестирукого Махакалы и его окружения в тексте «Ритуал умилостивления и подношения торма Быстродействующему Защитнику Мудрости Шестирукому Махакале» // Oriental Studies. 2021. Т. 14. № 3. С. 568-580. DOI: 10.22162/26190990-2021-55-3-568-580

\title{
The Image of the Six-armed Mahakala and His Retinue in the Text «The Ritual of Propitiation and the Offering of the Torma for the Swift-Acting Wisdom Protector, the Six-armed Mahakala»
}

\section{Soelma R. Batomunkueva ${ }^{1}$}

${ }^{1}$ Institute for Mongolian, Buddhist and Tibetan Studies of the Siberian Branch of the RAS (6, Sakhyanova St., 670047 Ulan-Ude, Russian Federation)

Cand. Sc. (Philosophy), Junior Research Associate

iD 0000-0002-5060-0296. E-mail: soelmul@mail.ru

\author{
(C) KalmSC RAS, 2021
}

(C) Batomunkueva S. R., 2021

\begin{abstract}
Introduction. This article deals with the analysis of a ritual text devoted to the Six-Armed Mahakala. Mahakala is one of the most powerful protectors of Tibetan Buddhism. The article gives a description of the Six-Armed Mahakala and his retinue and discusses the structure of the ritual text rendering its content and describing the rules and the sequence of acts in propitiating the deity. It is pointed out that the text is a compilation and some of the original authors are identified whose works were used in the ritual text signed by Khedrup Je. Also, the text is most voluminous and includes the discussions of a great number of other pertinent rituals. The aim of the present paper is the discussion and the interpretation of the image and attributes of the Six-Armed Mahakala based on a fragment of the text, translated and introduced for the academic community. Data and methods. The text "The Ritual of Propitiation ..." is used as the research material; the method employed is descriptive, complemented by methods of structural-semantic, conceptual, and contextual analysis. Results. The iconography of the deity contained in the text presents a description that includes a detailed explanation of some of the deity's elements. This allows to reveal the wrathful character of the fierce Dharmapala and shows that all the elements, such as attributes, gowns, adornments, postures, and gestures have deep symbolic meanings associated with philosophical and religious ideas, as well as with the ethical norms of Buddhism. This preliminary research, including the structuring and the analysis of the text under study, indicates the relevance, as well as the urgency of further examination of the introduced material, granted that ritual texts are seen as helpful additional sources for the study of the Buddhist deities.
\end{abstract}

Keywords: Buddhism, Buddhist pantheon, Mahakala, dharmapala, Buddhist tests, Buddhist ritual Acknowledgements. The reported study was funded by government subsidy — project name 'The Oriental Languages and Archival Documents of the Peoples of Russia and Inner Asia in the Context of Inter-Civilization Interaction, $18^{\text {th }}$ - Early $21^{\text {st }}$ Centuries' (state reg. no. 121031000302-9).

For citation: Batomunkueva S. R. The Image of the Six-armed Mahakala and His Retinue in the Text «The Ritual of Propitiation and the Offering of the Torma for the Swift-acting Wisdom Protector, the Six-armed Mahakala». Oriental Studies. 2021. Vol. 14 (3): 568-580. (In Russ.). DOI: 10.22162/26190990-2021-55-3-568-580 


\section{Введение}

Буддийская литература располагает огромным количеством разнообразных текстов философского, религиозного и исторического содержания. Особое место среди них занимают тексты культового, ритуального назначения.

Обрядовая литература буддизма очень обширна и разнообразна. Эти тексты составляют неотъемлемую часть буддийского письменного наследия, изучение и научная разработка которых необходима для более целостного и комплексного знакомства с культами буддийских божеств и ритуалом. Как «регламент» культовой деятельности способов и форм почитания, подобные тексты содержат много сведений, полезных в исследовании, к примеру, передающих иконографию божеств, историю самой практики и прочие подробности и детали этого сакрального действия. Они показывают богатство буддийского пантеона, способы и формы почитания божеств. С помощью интерпретации различных атрибутов и элементов иконографии божеств можно определить степень влияния на буддизм той или иной автохтонной традиции. Сведения из таких источников полезны и необходимы для обогащения имеющейся базы исследований по культам буддийских божеств, также актуально введение в научный оборот и самих текстов.

Письменное наследие буддизма формировалось и дополнялось на протяжении многих столетий. Л. Е. Янгутов отмечает, что первичным текстом в буддизме являются сутры, считающиеся высказываниями самого Будды, однако в результате того, что они были записаны в разное время различными людьми, эти тексты не лишены влияния записывающего, и поэтому зародилось множество комментариев к ним - шастр [Янгутов 2009: 4].

Кроме сутр и шастр, к письменной традиции следует отнести различные произведения апологического и художественного характера, тексты ритуальной практики, включающие молитвы и мантры, призывания и восхваления [Янгутов 2009: 4].
Ритуальные тексты представляют собой не просто совокупность зафиксированных знаков, но некую систему со своим устройством. Если сакральные тексты составляют суть определенного религиозного учения, то ритуальные тексты становятся своего рода пособием, инструкцией к применению культа. Иными словами, с помощью ритуальных текстов упорядочивается, структурируется религиозное действие по отношению к культу.

Буддийский культ и ритуал отличаются богатством образов, сложнейшей иерархической структурой божеств и множеством символов. В многоликом буддийском пантеоне важное место занимают дхармапалы ${ }^{1}-$ защитники Учения, к разряду которых относится Махакала. Это божества, призванные охранять и защищать буддийское учение. Шестирукий Махакала является одним из наиболее популярных божеств буддийского пантеона. История возникновения культа Махакалы связана с именем знаменитого индийского йогина - махасиддха Шаварипы $^{2}$, который, согласно традиции, первым узрел образ божества и впоследствии составил садхану $y^{3}$, посвященную ему.

По мнению А. В. Зорина, эта садхана или, как он пишет, «описание, данное Шаварипой после встречи с Махакалой, стало основой для литературной и иконографической разработки его образа» [Зорин 2005: 121]. Подобная практика применения результатов визуализации мастеров нередко используется в буддийском искусстве при передаче образов божеств. И действительно, если приписываемый Шаварипаде текст гимна очень краток, то в процессе дальнейшей разработки он был существенно увеличен и дополнен.

Другой немаловажный момент, на который стоить обратить внимание: если в изначальной версии текста гимна Махакале он

${ }^{1}$ Санскр. Dharmapāla.

${ }^{2}$ Тиб. dpal ldan sha ba ri, санскр. Śabara.

${ }^{3}$ Tиб. sgrub thabs - букв. «метод достижения, выполнения», санскр. sādhana - руководство по совершению определенных действий по визуализации и выполнению практики божества. 
описывается, начиная с ног, то в дальнейших редакциях текста его описывают, начиная с головы, а точнее - в начале указывается темно-синий цвет его тела, далее отмечается, что у божества одна голова и т. д.

А. В. Зорин также отмечает, что подобные гимны или cmompbl, посвященные Буддам, бодхисаттвам и различным тантрическим божествам, возникли в Индии в рамках жанра кавья ${ }^{4}$, но все же большая часть буддийских гимнов имеет слабое отношение к художественной литературе, будучи служебными текстами, использовавшимися в практических целях: иконографии, ритуале и др. [Зорин 2005: 121]. Однако в последующем все же уделялось большое внимание художественной, именно эстетической, стороне сложения подобного рода гимнов и ритуальных текстов.

\section{Структурно-содержательные особен- ности текста}

Исследуемый текст «Ритуал умилостивления и подношения торма ${ }^{5}$ Быстродействующему Защитнику Мудрости - Шестирукому Махакале» (тиб. myur mdzad ye shes kyi mgon po phyag drug pa'i gtor chog bskang gso cha lag dang bcas pa bzhugs so) хранится в тибетском фонде Центра восточных рукописей и ксилографов Института монголоведения буддологии и тибетологии СО РАН под инвентарным номером 1055 ТТ-07694 и представляет собой ксилографическое издание на русской бумаге белого цвета на 47 листах. Границы внешних рамок составляют $45,0 \times 9,03$ см, внутренних $-8,0 \times 6,5$ см. Пагинация в тексте постраничная, и на страницах $1 \mathrm{~b}, 2 \mathrm{a}$ - три строки, на обеих сторонах страниц, начиная с $2 \mathrm{~b}$ по 46b, - 5 строк, на последней - 47a странице - 4 строки.

${ }^{4}$ Санскр. Kāvyá - литературный стиль, в котором используется большое количество фигур речи, метафор, сравнений и гипербол для более эффектного выражения.

5 Тиб. gtor ma - ритуальное подношение, иногда называют балин (санскр. bali). Символические подношения божествам разных форм, размеров, цветов, с разнообразными узорами, изготавливаемые преимущественно на основе из ячменной муки, масла и воды. Наиболее распространенными, простыми и «удобными» являются торма в форме треугольной пирамиды или конуса. Однако существуют очень сложные как в изготовлении, так и в оформлении торма.
На некоторых листах посередине имеется штемпель «Фабрика наследников Сумкина № 7». Это позволяет говорить о том, что данный текст был издан предположительно в период с конца XIX - начала XX в., так как такой штемпель начал применяться с 1867 г. ${ }^{6}$

В тексте отсутствуют какие-либо печати, указывающие на место издания, и в колофоне также не упоминаются место и дата издания, однако внешний вид, особенности графики, указывают на то, что это издание Агинского (Цугольского) дацана «Дечен Лхундублин». Последнее предположение находит подтверждение в каталоге дацана, подготовленном к изданию А. А. Базаровым и Д. Шахановым [Bazarov, Namgyal 2017: 19]. В тибетском фонде Центра также имеются и дублетные издания данного текста, имеющие шифр ТТ-12476, ТТ-07703, ТТ07694, ТТ-07656.

Рассматриваемый текст является одним из наиболее обширных текстов, посвященных божеству, который включает в себя много сопутствующих ритуалов. Автором-составителем текста, как сообщается в его колофоне, является «высокообразованный Держатель ваджра Гелек Пелзанг» [myur mdzad: 47a]. Более известный как Кхедруб Чже 7 , он являлся одним из выдающихся учеников Цонкапы. Это сочинение также входит в состав его сумбума ${ }^{8}$.

Несмотря на то, что авторство приписывается Кхедрубу Чже, на основании разделов текста, авторами которых являются разные персоналии, можно говорить о его компилятивном характере, что часто практикуется в ритуальной литературе. В качестве авторов отдельных частей текста упоминаются махасиддха Шаварипа ${ }^{9}$ [myur mdzad: 14a, 36a], Рахула $^{10}$ [myur mdzad: 25a, 40a], Майтри-

${ }^{6}$ Подробнее про штемпель см.: [Клепиков 1959; Цыпкин 2013].

7 В монголо-бурятском буддизме Кхедруб Чже (1385-1438) известен в несколько ином произношении - Кхайдуб Гэлэг Балзанбо. В период с 1431-1438 гг. он являлся третьим по счету после Цонкапы и Дармы Ринчена Держателем Золотого Трона — лидером школы гелук.

${ }^{8}$ Тиб. gsung 'bum - собрание сочинений.

${ }^{9}$ Тиб. grub chen sha wa ri.

${ }^{10}$ Тиб. rA hu la. Также известен как Рахулагупта. 
па $^{11}$ [myur mdzad: 39b, 40b, 42a], Кхюнгпо Нелджор ${ }^{12}$ [myur mdzad: 27b, 35a], Дампи Минчен $^{13}$ [myur mdzad: 24a], Кхедруб Чже / Гелек Пелзанг [myur mdzad: 6b, 41a, 42b, 47a], Сангье Еше ${ }^{14}$ [myur mdzad: 28b], Кхедруб Шентон ${ }^{15}$ [myur mdzad: 17a], Чой Дже ${ }^{16}$ [myur mdzad: 21a], Кунсан Цегпа ${ }^{17}$ [myur mdzad: 29a], Брамзе Чогсид ${ }^{18}$ [myur mdzad: 37b], Чолви Тинле ${ }^{19}$ [myur mdzad: 44a], Лодой Сенге ${ }^{20}$ [myur mdzad: 45a].

Компилятивность текста в буддийской традиции является показателем того, что все знания и правила передавались, как и положено, от учителя к ученику. По мнению К. М. Герасимовой, обрядники, посвященные защитникам учения, разнохарактерны и, как она пишет, «в них использованы индуистские тексты и буддийские концепции индийских дхармапал» [Герасимова 1989: 42].

Исследуемый текст не только регламентирует правила и последовательность совершения ритуала, но также содержит достаточно обширные сведения по иконографии божества и информацию по линии преемственности передачи данной практики. Последняя представлена списком: Майтрипа, Рахула, Кхедуб Кхюнгпо, Ринчен Цондуй ${ }^{21}$, Бонтон Кьергангпа ${ }^{22}$, Ньентон Пеба' ${ }^{23}$, Чойдже Сангье, Кхедуб Шентон, Мучен Гьялцен Пелзанг ${ }^{24}$, Нганчед Дорчже Чжонну ${ }^{25}$, Намкхай ${ }^{26}$, Цонкапа, Кхедуб Гелек Пелзанг, Чокьи Гьялцен ${ }^{27}$, Чой Дорч-

${ }^{11}$ Тиб. mee tri ba/maitri pa. Также известен как Майтригупта.

${ }^{12}$ Тиб. khyung po rnal 'byor, 978/990-1127.

${ }^{13}$ Тиб. dam pa'i min can.

${ }^{14}$ Tиб. mkhas grub sangs rgyas ye shes, 1525 1590.

${ }^{15}$ Тиб. mkhas grub shangs ston, 1234-1309.

${ }^{16}$ Тиб. chos rje sangs rgyas.

${ }^{17}$ Тиб. kun bzang brtsegs pa.

${ }^{18}$ Тиб. bram ze mchog srid.

${ }^{19}$ Тиб. bcol ba'i 'phrin las.

${ }^{20}$ Тиб. blo gros seng ge.

${ }^{21}$ Тиб. rin chen brtson 'grus, 1110-1170.

${ }^{22}$ Тиб. dbon ston skyar sgang pa, 1154-1217.

${ }^{23}$ Тиб. gnyan ston spas pa, 1175-1255.

24 Тиб. mus chen rgyal mtshan dpal bzang, XIII в

${ }^{25}$ Тиб. sngags 'chad rdo rje gzhon nu, XIV в.

${ }^{26}$ Тиб. nam mkha', XIV в.

${ }^{27}$ Тиб. chos kyi rgyal mtshan, 1402-1473. же ${ }^{28}$, Лобсан Дондуп ${ }^{29}$, Кхедуб Сангье Еше. Вполне логично, что некоторые учителя, отмеченные в качестве авторов, упоминаются и в линии передачи учения.

Содержание текста позволяет разделить его на следующие части:

1) вводная часть - поклонение и обращение к Махакале; подготовка необходимых ритуальных принадлежностей и ритуального пространства [myur mdzad: 1-2b];

2) визуализация божества, его свиты и окружения [myur mdzad: 2b-6b];

3) приглашение [myur mdzad: 6b-9b];

4) освящение внутреннего подношения [myur mdzad: 9b-11b];

5) почитание Учителей и просьба о даровании благословления [myur mdzad: 11b-14a];

6) раскаяние [myur mdzad: 14a-17a];

7) освящение жертвенных подношений [myur mdzad: 17a-17b];

8) ритуал умилостивления [myur mdzad: 17b-21a];

9) подношение Махакале его основных атрибутов [myur mdzad: 21a-24a];

10) призыв к действию [myur mdzad: 24a-27b];

11) отбрасывание дурного [myur mdzad: 27b-29a];

12) рецитация мантры Махакалы и мантр членов его свиты [myur mdzad: 29a-31b];

13) подношение торма Махакале и членам его свиты, внешнее и внутреннее подношения [myur mdzad: 31b-35a];

14) подношение торма шибдакам ${ }^{30}$ [myur mdzad: 35a-36a];

15) восхваление Махакалы и его свиты [myur mdzad: 36a-42b];

16) восхваление 75 Хранителей чистых земель [myur mdzad: 42b-44b];

17) благословление [myur mdzad: $44 b-45 a]$

18) просьба о снисходительном отношении [myur mdzad: 45a];

19) посвящение заслуг [myur mdzad: 45b];

20) призывание счастья [myur mdzad: 45b-46b];

21) колофон [myur mdzad: 46b-47a].

${ }^{28}$ Тиб. chos rdo rje, XV в.

${ }^{29}$ Тиб. blo bzang don grub, 1504-1565.

${ }^{30}$ Тиб. gzhi bdag — хозяева местности. 


\section{Образ Махакалы и его свиты}

Буддийский пантеон чрезвычайно богат и разнообразен, многолик и полисемантичен. В нем слились образы божеств, разных по происхождению и функциям, поскольку возникновение и развитие буддизма происходило в рамках богатейшей и сложнейшей индийской культуры, которая в свою очередь вобрала в себя наследие предшествовавших ей культурных и духовных традиций, а также обычаи регионов своего дальнейшего распространения. Последнее способствовало дальнейшему эволюционированию всех звеньев буддийской религиозной и философской традиции, в том числе и иконографии.

По мнению Б. Бхаттачарьи, источником буддийской иконографии стали древние санскритские тексты, содержащие сведения и руководства по созданию образов божеств, и в дальнейшем эти тексты распространились в те страны, где обретала популярность буддийская религия [Bhattacharyya 1958: 8$]^{31}$.

Вместе с тем в этих регионах формировалась своя уникальная иконографическая традиция, которая диктовалась местными культурными особенностями. Д. Джексон отмечает, что большинство исследователей сходятся во мнении, что следует различать два периода в становлении тибетского искусства. Первый связан с иностранным непальским, кашмирским, но главным образом индийским влиянием, а второй характеризуется формированием собственно тибетского стиля, который также не был лишен китайского влияния [Jackson 1996: 69] ${ }^{32}$.

У каждого разряда пантеона имеются свои особенности. Характер и облик божеств разных уровней - мирных и гневных - имеет групповые отличия, обусловленные их спецификой. Большинство буддийских дхармапал предстают в таком облике: гневные, грозные, со множеством глаз, голов и рук, преимущественно черного или темно-синего цвета, с разнообразными ужасающими атрибутами.

К. М. Герасимова отмечает, что тип телосложения, форма лица, глаз, характерная поза - все эти формальные признаки имеют знаковое значение, определяют функци-

\footnotetext{
${ }^{31}$ Перевод наш. - C. Б.

${ }^{32}$ Перевод наш. - C. Б.
}

ональную и сущностную характеристику божества, указывают на его положение в системе пантеона. Божества, относящиеся к высшему рангу, наделены высоким ростом, стройным и легким телосложением. Божества, заимствованные из индуистского пантеона, также обладают красивым и стройным телом. Дхармапаль наделены так называемым героическим телом: тяжелый торс, большой живот, короткая и толстая шея, большая голова с круглым или приближенным к квадратной форме лицом [Герасимова 1971: 95]. Они имеют плотное, тучное тело, короткие, но крепкие руки и ноги, одну или несколько голов, множество рук. Их тела часто измазаны человеческим жиром, кровью или пеплом погребального костра. Выражение лица дхармапал — гневное; рот, из которого стелется туман болезней, оскален; налитые кровью глаза выпучены и озлоблены [Nebesky-Wojkowitz 1993: $6]^{33}$.

Образ Шестирукого Махакалы соответствует всем этим «требованиям» к внешности грозного дхармапалы. Все его украшения, одеяния, атрибуты, жесты и другие характеристики, как, впрочем, и всех божеств буддийского пантеона, имеют глубокую смысловую нагрузку, и их символика вписывается в общую систему сложных буддийских представлений - как философских, так и религиозных.

Согласно описанию в тексте, Шестирукий Махакала стоит в так называемой «танцующей» позе с правой согнутой и левой выпрямленной ногой, попирая Белого Слоноликого владыку (Ганеша, Винаяка). Главными характеристиками Шестирукого Махакалы являются: одно лицо, три глаза, шесть рук, корона из пяти черепов, темно-синий цвет тела. Относительно последней характеристики хотелось бы отметить: несмотря на то, что имя божества Махакалы путем калькирования с санскрита на тибетский переводят как «Великий Черный», в большинстве текстов и иконографических изображений божества он передается синим цветом, преимущественно темно-синим ${ }^{34}$.

Существуют и другие, непопулярные в буддизме, варианты перевода имени Махакалы: «Великое время» или «Великий бог

${ }^{33}$ Перевод наш. - C. Б.

${ }^{34}$ В рассматриваемом тексте цвет Шестирукого Махакалы передается словом «nag mthing». 
времени». А. В. Зорин отмечает, что Махакала изображается: «с телом иссиня-черного цвета: считается, что как черный растворяет в себе все цвета, так же и Махакала объемлет собой все формы и таким образом выступает воплощением высшей реальности, к достижению которой стремятся буддисты. Поэтому, по-видимому, здесь мы имеем дело с намеренной игрой слов и в имени «Махакала» зашифрованы оба смысла, что вообще присуще индийской словесности, тяготеющей к объемности образов» [Буддийские 2015: 17].

Цветовое разногласие при передаче образа божеств, вероятно, не имеет особого значения, поскольку в санскрите нет отличия между черным и синим, а в пределах полутонов, относящихся к этим цветам, вполне допустимо подобное применение. А. А. Терентьев отмечает: «фиолетовый цвет может быть эквивалентен синему, а синий теоретически равен голубому и может взаимозаменяться с черным - все эти различия не имеют иконографического смысла, являясь лишь отражением стиля художника. В эту же категорию «черного» будет отнесен и «пепельный» цвет» [Терентьев 2004: 158].

Иными словами цветовой фактор, как один из определительных, может быть применен не ко всем божествам, а лишь в рамках определенных групп.

В состав первичной свиты Шестирукого Махакалы входят Палден Лхамо ${ }^{35}$, Кшетрапала, Джинамитра, Таккираджа и Тракше. Второстепенное окружение, согласно тексту, состоит из семидесяти пяти Хранителей чистых земель. В тексте говорится о том, что местом обитания Махакалы является кладбище Прохладная роща, ${ }^{36}$ и пребывает он там перед сандаловым деревом [myur mdzad: 6b]. Это кладбище является одним из восьми великих кладбищ Индии ${ }^{37}$. Согласно традиции, во время глубокой медитации в

35 Подробнее о функционировании культа богини, описании ее форм см.: [Сыртыпова 2003].

36 Шитавана (санскр. śītavana), тибетская калькированная версия - Силвицэл (тиб. dur khrod bsil ba'i tshal).

${ }^{37}$ Тиб. dur khrod chen po brgyad. Считается, что именно в таких местах достигаются мистические и сверхъестественные способности, называемые сиддхи (тиб. dngos grub). одной из пещер Прохладной рощи махасиддха Шаварипа узрел в небе образ божества, и считается, что именно тогда он и получил от Махакалы его сердечную мантру и садхану [ye shes kyi].

Ниже нами представлен перевод части текста (страницы с $2 \mathrm{~b}$ по 9b), описывающей Махакалу и его свиту. Здесь следует добавить, что в самом тексте «Ритуал умилостивления...» даются разные и одновременно повторяющиеся эпитеты божества, но основное описание дается на этих страницах.

Перевод ${ }^{38}:$ «... [myur mdzad: 2b] Из природы пустоты из слога ПАМ возникает лотос, из слога РАM - солнечный диск, над ним из слога ГАМ [возникает] лежащий на спине Белый Слоноликий Владыка ${ }^{39}$, [myur mdzad: 3a] с повернутой вправо головой, в правой руке держащий габалу ${ }^{40}$, в левой белый редис ${ }^{41}$. Над этим из слога ХУМ возникает дигук ${ }^{42}$, отмеченный слогом ХУМ, из которого испускается луч света, уничтожающий все помрачения. Вернувшись обратно, этот луч уменьшается, и из него возникает Быстродействующий Защитник Мудрости

с телом темно-синего цвета,

с одним лицом и шестью руками, неимоверно пылающий, свирепый и могущественный,

с гневным лицом и оскаленными острыми клыками,

38 Основная часть примечаний к переводу составлена на основе Тибетологического словаря Лобсан Тинлея и работ Р. Бира, В. П. Андросова, А. А.Терентьева [Trinle 2002; Бир 2011; Бир 2013; Андросов 2011; Терентьев 2004].

39 Тиб. tshogs bdag dkar po glang po che; санскр. Gaṇeśa, Vighneśa, Vighnarāja. Последние два означают «Владыка препятствий» или «Царь препятствий», и, возможно, Шестирукий Махакала, будучи хранителем буддийского учения, попирает его, дабы пресечь препятствия, которые он может зачинить. Подробнее о Ганеше в буддизме см.: [Лепехова 2020; Бурмистров 2014].

40 Тиб. thod pa, ka pa la, ban dha; санскр. kapāla - ритуальная чаша из человеческого черепа.

${ }^{41}$ Тиб. la phug; санскр. mūlaka - белый peдис - является одним из наиболее популярных растительных атрибутов божеств, считается любимым лакомством Ганапати, и поэтому его часто изображают держащим это растение.

42 Тиб. gri gug; санскр. karttṛkā — ритуальный изогнутый нож. 
с тремя красными глазами, сверкающими подобно молнии,

с суровыми, гневными складками на лице,

со вздыбленными вверх желто-красными волосами,

с пылающими, подобно огню конца времен, бровями и усами,

с изогнутым языком,

[myur mdzad: 3b] издающий, подобно дракону, звуки «ха, ха».

В первой правой руке [он] держит дигук, во второй - четки из черепов ${ }^{43}$, в третьей - сильно гремящий дамару ${ }^{44}$ из черепа. В первой левой руке [он] держит габалу (капалу) с кровью, во второй - трезубец ${ }^{45}$, в третьей - ваджрный аркан ${ }^{46}$.

Волосы [Махакалы] обвиты синей змеей, [Махакала] с красными серьгами в ушах, с разноцветными браслетами на плечах, с белым ожерельем, с золотыми браслетами на руках, с зеленой гирляндой, с белым поясом и браслетами, украшающими ногу, с юбкой из свежесодранной тигровой шку-

${ }^{43}$ Тиб. thod pa'i 'phreng ba; санскр. Māla атрибут большинства гневных божеств, может состоять из двенадцати, шестнадцати и двадцати одной бусин-черепов, которые символизируют свободу от двенадцати звеньев зависимого возникновения, шестнадцать пустотностей и двадцать одну категорию чистой мудрости соответственно

${ }^{44}$ Тиб. rnga chung, Da ma ru, cung te'u, gtan la dbab pa; санскр. damaru - ритуальный ручной барабанчик разных размеров в форме, приближенной к песочным часам.

${ }^{45}$ Тиб. rtse gsum, tri shu la; санскр. triśūla символика трезубца в буддизме; имеет много значений, в том числе: Три Драгоценности (Будда, Сангха и Дхарма) и Три корзины (Абхидхарма, Виная и Сутра). Считается, что шиваистский трезубец вошел в буддизм как атрибут гневных божеств, символизирующий разрушение трех ядов (неведение, привязанность и гнев), трех тел и времен.

${ }^{46}$ Тиб. rdo rje zhags pa. В мирном аспекте ваджрный аркан представляет привязывание мудрости к уму практикующего, а в паре с крюком - союз внимательности и ясного понимания. В гневном аспекте - связывает препятствующих. Так, эти три вида действия представляют три аспекта буддийской подготовки - мудрость, медитацию и дисциплину. ры $^{47}$, завязанной шелковым зеленым поясом, со свисающим животом. [Так] все части тела удостоены внимания, и [они] хорошо украшены. [myur mdzad: 4a] [Махакала] с головой, украшенной диадемой из пяти высушенных человеческих черепов ${ }^{48}$,

с ожерельем из пятидесяти свежих кровоточащих голов ${ }^{49}$,

со лбом, намазанным синдхуром ${ }^{50}$,

с макушкой, украшенной знаком Акшобхьи ${ }^{51}$,

с руками и ногами, украшенными звенящими бубенцами,

облаченный в свежесодранную слоновью шкуру ${ }^{52}$,

с правой согнутой и левой выпрямленной ногой,

в центре пылающего огня мудрости в позе танца ${ }^{53}$ пребывает.

Слева из слога ДЖО возникает Единственная Мать - Владычица камадхату ${ }^{54}$ с телом черного цвета, одноликая, двурукая. Правой рукой размахивает неистово пылающим огнем мечом, в левой, у сердца держит наполненную свежей кровью габалу.

[myur mdzad: 4b] C оскаленными клыками,

47 Тигровая шкура означает контроль над ядами гнева и ненависти.

48 Диадема с пятью черепами символизирует устранение или, как иногда называют, победу над пятью клешами (тиб. nyon mongs) и скандхами (санскр. skandha; тиб. phung po lnga) или совокупностями: неведение, страсть, гнев, зависть, гордыня и форма, чувство, восприятие, сознание, отпечатки кармы, что также символизирует пять Дхьяни-Будд.

49 Ожерелье из 50 свежесрубленных голов символизирует очищение речи. Число 50 это 16 гласных и 34 согласных сансктритского алфавита. Ожерелье из голов является одним из показателей мужской формы божества, тогда как женские формы носят ожерелье из черепов.

${ }^{50}$ Тиб. $\sin +\mathrm{d}+$ hura, санскр. sindūra - порошок красноватого цвета, из которого изготавливают краску, известную как свинцовый сурик.

${ }^{51}$ Имеется в виду пятиконечный ваджр.

${ }^{52}$ Слоновья шкура означает победу над гордыней.

${ }^{53}$ Tиб. gar stabs. Также называют позой покорения.

${ }^{54}$ Тиб. ma gcig 'dod pa'i khams kyi dbang phyug ma - один из эпитетов Палден Лхамо; камадхату (тиб..'dod kham) — сфера желаний. 
с суровыми гневными складками на лице,

со вздыбленными вверх и украшенными на концах павлиньими перьями ${ }^{55}$ волосами,

с накидкой из свежей слоновьей шкуры,

с юбкой из ячьей шерсти, опоясанной черной змеей,

с телом, обмазанным и украшенным каплями крови, жиром и человеческим пеплом ${ }^{56}$,

из центра живота восходит солнце,

в окружении пишачей ${ }^{57}$ и даков ${ }^{58}$,

восседает на муле.

Перед Махакалой в центре бесчисленного множества ракшасов ${ }^{59}$ из слога ТЧИМ возникает Кшетрапала ${ }^{60}$

с телом темно-синего цвета,

одноликий и двурукий,

с оскаленным лицом,

[myur mdzad: 5a] с устрашающим врагов диким воплем,

с тремя красными глазами, отражающими дурные людские взгляды.

В правой руке [он] вздымает дигук, нависающий и отсекающий аорту врага, в ле-

55 У некоторых дхармапал в качестве украшения на голове могут присутствовать павлиньи перья, которые символизируют преобразование пяти ядов - неведения, страсти, гнева, гордыни и зависти.

${ }^{56}$ Вместе составляют byugs pa'i rdzas gsum, относящихся к восьми кладбищенским облачениям. Человеческий пепел (thal chen gyi tshom bu) наносится на лоб, кровь (khrag gi thig le) на нос и щеки, а человеческий жир (zhag gi zi ris) - на подбородок и горло.

${ }^{57}$ Тиб. sha za; санскр. piśāca — класс демонов, злобных и вредоносных духов, питающихся кровью и плотью. Считается, что они обитают на кладбищах и на пустырях, в пустых зданиях, на перекрестках дорог. Могут принимать любой облик.

${ }^{58}$ Тиб. mkha 'gro, то же, что и тиб. dpa' bo (герои). Мужской эквивалент дакинь (mkha' 'gro ma) - йогинь, реализовавших высшие достижения и способных проявляться как охранительницы учения.

59 Тиб. gnod sbyin; санскр. rākșasah — вид вредоносных, злых демонов, способных принимать разнообразные формы животных. Проявляют активность преимущественно в ночное время.

${ }^{60}$ Тиб. $\mathrm{k}+$ She tra $\mathrm{pA}$ la. вой руке, поднося к лицу, держит габалу с сердечной кровью врага.

[Кшетрапала] со вздыбленными вверх красно-желтыми волосами,

с головой, украшенной высушенным черепом,

с устрашающим и отвратительным телом,

в центре пламени восседает на черном бешеном медведе.

Справа от Махакалы на круглом лотосном солнечном диске из слога ДЗАМ возникает одноликий, двурукий, с телом якшаса ${ }^{61}$ красного цвета Владыка Джинамитра $^{62}$. [myur mdzad: 5b] В правой руке $[о н]$ держит гремящую, сделанную из человеческого черепа дамару, в левой — габалу с кровью.

За спиной Махакалы на круглом лотосном солнечном диске из слога ДАМ возникает Шиндже Таккираджа ${ }^{63}$ с телом темно-синего цвета, одним лишь взглядом забирающий жизнь врага, одноликий, двурукий, в правой руке [он] держит дамару из черепа, левая рука — в мудре угрозы ${ }^{64}$.

Слева от богини [Палден Лхамо] из слога ДРАГ возникает Тракше ${ }^{65}$ с телом черного цвета, с одним лицом и двумя руками. Правой рукой [он] размахивает красным оружием, в левой [руке] у сердца держит габалу с кровью. [Тракше] с тремя свирепыми, устрашающими глазами [myur mdzad: 6а] в окружении ста тысяч вредоносных якшасов восседает в парчовом одеянии синего цвета посреди огня на темном коне с белым пушком на копытах.

В десяти внешних сторонах от них [основного окружения] - свита из 10 защит-

61 Тиб. gnod sbyin (букв. «причиняющий зло»), санскр. yakșa - духи природного происхождения, обитающие в горах, лесах и деревьях. Иногда называют хранителями природных богатств.

${ }^{62}$ Тиб. dzi na mi tra.

${ }^{63}$ Тиб. gshin rje Tak+ki rA dza.

${ }^{64}$ Тиб. sdigs mdzub, санскр. tarjan̄̄ — этот жест складывается из зажатого или «приоткрытого» кулака с поднятым указательным пальцем, который может быть чуть согнутым, напоминая крюк.

${ }^{65}$ Тиб. tra kshad. 
ников сторон ${ }^{66}$, [также] 8 Махадев ${ }^{67}, 8$ классов нагов ${ }^{68}$, божества 8 планет ${ }^{69}, 4$ Махараджи $^{70}, 28$ божеств созвездий ${ }^{71}, 9$ Великих

${ }^{66}$ Тиб. phyogs skyong ba, санскр. dikpāla: shar phyogs skyong ba brgya byin (Indra) — Bocток, lho phyogs skyong ba gshin rje (Yamarāja) юг, nub phyogs skyong ba chu lha (Varuna) запад, byang phyogs skyong ba gnod sbyin (Kubera) - север, shar lho'i phyogs skyong me lha (Agni) - юго-восток, lho nub phyogs skyong srin po (Nirrtī) - юго-запад, nub byang phyogs skyong rlung lha (Vāyu) - северо-запад, byang shar phyogs skyong dbang ldan (İsāna) — северо-восток, steng du tshang pa (Brahmā) — верх или зенит, 'og tu sa'i lha mo bcas (Viṣnu) — низ или надир.

${ }^{67}$ Тиб. Tha chen po brgyad, санскр. Mahādevas: shar du dbang phyug nag po (İśvara), lhor brgya byin (Indra), nub tu tshangs pa (Brahmā), byang du khyab mjug (Vișnu), shar lhor 'dod pa'i dbang phyug (Uma), lho nub tu tshogs bdag glang sna (Gaṇapati), nub byang du 'bring gi ri ti (Bhṛngiriți), byang shar gzhon nu dong drug (Kārttikeya).

${ }^{68}$ Тиб. klu chen po brgyad, санскр. nāgarāja: mtha' yis sngon po (Śeșa), 'jog po dmar po (Takșaka), dung skyong ser po (Śan்khapāla), rigs ldan khra bo (Kulika), pad+ma dkar po (Padma), stobs rgyu ljang ku (Karkoțaka), nor rgyas dkar po (Vāsuki), pad+ma chen po dkar po (Mahāpadma).

${ }^{69}$ Тиб. gza' chen po brgyad: shar du pa sangs (Śukra, Венера), lhor phur bu (Bṛhaspati, Юпитер), nub tu zla ba (Candra, Луна), byang tu lhag pa (Budha, Меркурий), shar lhor mig dmar (Mañgala, Mapc), lho nub tu sgra gcan (Rahu), nub byang du nyi ma (Sūrya), byang shar du spen pa (Śani, Caтурн).

${ }^{70}$ Тиб. 'jig rten skyong ba bzhi, санскр. lokapāla. Четыре Махараджи - Дхритараштра (yul 'khor bsrungs) охраняет восточную сторону, Вайшравана (rnam thos sras) - северную, Вирупакша (spyan mi bzang) - запад, Вирудхи ('phags skyes po) - хранитель южной стороны.

${ }^{71}$ Тиб. rgyu skar nyi shu rtsa brgyad, санскр. nakshatra. Тиб., санскр. и русс. соотв: smin drug, Kṛttikā; snar ma, Rohini; mgo, Mrigashīra; lag pa, Ārdrā; nabs so, Punarvasu; rgyal, Pushya; skag, Ashlesha; rta pa, Maghā; gre, Pūrva Phalgunī; dbo, Uttara Phalgunī; me bzhi, Hasta; nag pa, Chitrā; sa ri, Svātī; sa ga, Vishākhā; lham tshams, Anurādhā; snron, Jyeshtha; snrubs, Mūla; chustod, PūrvaAshādhā; chus mad, Uttara Ashādhā; grobzhin, Abhijit; byi bzhin, Shravana; mon gre, Dhanistha; mon gru, Shatabhisha; khrums stod, Pūrva Bhādrapadā; khrumssmad, Uttara Bhādrapadā; nam gru, Revatī; tha skar, Ashvinī; bra nye, Bharanī.
Бхайрав $^{72}$ - [вместе] 75 Хранителей чистых земель $^{73}$, окруженные собранием бхут ${ }^{74}$ трех сфер существования ${ }^{75}$.

Во внешней стороне от них [75 Хранителей чистых земель] - океан армии свирепых и беспощадных плотоядных и кровожадных дамченов ${ }^{76}$, наполняющих все пространство ужасающим видом, с налитыми кровью глазами, с раскрытыми и оскаленными ртами, держащими различные оружия, [myur mdzad: 6b] в одно мгновенье способные отнять жизнь всех живых существ. Глава и свита [все вместе] отмечены белым [слогом] ОМ на макушке, в горле красным [слогом] А, в сердце - синим [слогом] ХУМ.

От моего сердечного синего [слога] ХУМ исходит луч на юго-восток и в одно мгновенье приглашает с кладбищ Шитавани $^{77}$, находящегося перед сандаловым деревом, Махакалу вместе со свитой.

Хум! Великое божество Махакалу, проявившегося ради усмирения ядов, из неиз-

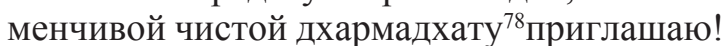
Прошу, приди, Махакала! Прошу, приди, Величественный! [myur mdzad: 7a] Божество, побеждающее врагов, приди! Хранитель, держащий знания, приди! Локапалачерный, приди! Армия свиты, приди! Окруженный якшами, Кшетрапала, приди! Океан дамченов, приди!

Могущественный Махакала с телом темно-синего цвета,

со вздыбленными вверх волосами,

сжигающий все препятствия пылающим изнутри огнем,

72 Тиб. 'jigs byed chen po dgu: 'jigs byed kyi bdag po, 'jigs byed bra mi ta, 'jigs byed bhE ra ba, 'jigs byed ku be ra, 'jigs byed ye shes bee ra, 'jigs byed bhE shan ta, 'jigs byed bi ti, 'jigs byed kA la bhE ra, 'jigs byed ga na pa ti

${ }^{73}$ Тиб. gtsang ris kyi mgon po bdun cu rtsa lnga po.

${ }^{74}$ Тиб. 'byung po, санскр. bhūta - род злых духов, вредоносных демонов. Часто являются перевоплощениями самоубийц или тех, кто умер в результате несчастного случая. Могут питаться кровью и плотью.

75 Тиб. srid pa gsum.

76 Тиб. dam can - букв. «обладающий обетом». Божества, ранее входившие в состав небуддийского пантеона, однако давшие клятву защищать его.

${ }^{77}$ Тиб. dur khrod chen po bsil ba'i tshal.

${ }^{78}$ Тиб. chos kyi dbyings. 
пребывающий в центре пламени, подобного огню кальпы, в позе покорения на опоре из клятвопреступных врагов,

с тремя гневными глазами, сверкающими подобно молнии [myur mdzad: 7b],

с острыми оскаленными клыками,

со свежесодранной слоновьей шкурой на спине,

с тигровой юбкой ниже живота,

с великолепной гирляндой из свежих человеческих голов,

с частями тела, украшенными змеей.

Ты [Махакала], усмиряющий темных нагов, велик! Из всех пор твоего тела, подобно искрам, исходят пауки и скорпионы. [Ты] заполняешь своей гривой три сферы обитания живых существ и уничтожаешь, стирая в пыль, три тысячи бхутов!

[Ты] в первой правой руке [держишь] пылающий дигук из метеоритного железа и разрезаешь [им] аорту вредоносных врагов-бхутов,

в первой левой руке, поднося ко рту, держишь габалу, наполненную кровью врага,

в правой средней [из шести] - [myur mdzad: 8a] пылающие четки из черепов, что есть [признак] памятования о существах шести миров,

в средней левой [из шести] — трезубец, символизирующий достижение плода трех тел,

последней правой яростно гремишь дамару, способной вызвать и покорить мамо ${ }^{79}$ и дакинь, которые придя и вкусив торма,

\section{Источники}

myur mdzad - myur mdzad ye shes kyi mgon po phyag drug pa'i gtor chog bskang gso cha lag dang bcas pa bzhugs so (= Ритуал умилостивления и подношения торма Быстродействующему Защитнику Мудрости - Шестирукому Махакале) // Тибетский фонд ЦВРК ИМБТ СО РАН. 1055. № ТТ 07694.

ye shes kyi - tA ra nA tha (Таранатха). Ye shes kyi mgon po phyag drug pa'i chos skor gyi byung tshul mdo tsam brjod pa (= Краткая история учения Шестирукого Махакалы). gsung 'bum tA ra nA tha/ ('dzam thang par ma/ (Собрание сочинений). Т. 21 [электронный pecypc] // Buddhist Digital Resource Center.

79 Тиб. та то - женские божества гневного характера, способные повелевать природными способствуют спасению от препятствующих врагов,

в последней левой руке [держишь] черный аркан, пленяющий врагов учения...».

\section{Заключение}

Текст «Ритуал умилостивления...» представляет собой подробное руководство по проведению обширного ритуала по почитанию Шестирукого Махакалы, его визуализации и различных подношений божеству. Этот текст имеет не только практическое значение с позиций адептов буддизма, но также и большую содержательную значимость при исследовании культов буддийских божеств. Иконография, представленная в тексте, достаточно подробно описывает Шестирукого Махакалу и его свиту: все атрибуты, одеяния, украшения, позы, жесты Шестирукого Махакалы и божеств в составе его окружения, которые имеют глубокое символическое значение, связанное с философскими, религиозными и этическими принципами буддийской традиции. Вероятно, что текст не является исчерпывающим, поскольку в богатой буддийской литературе имеются и другие тексты с более обширными сведениями по божеству, где содержится не только иконография, но также и иконометрия. Важное значение имеет линия преемственности данной практики, отмеченная в тексте, представляющая интерес для изучения. В целом же по структуре и сюжетной логике содержание текста стандартно для подобных ритуальных текстов.

URL: $\quad$ https://www.tbrc.org/\#!rid=W22276 (дата обращения: 10.02.2021).

\section{Sources}

Taranatha. A Brief History of the Six-Armed Mahakala's Practice. On: Buddhist Digital Resource Center. Available at: https://www. tbrc.org/\#!rid=W22276 (accessed: February 10, 2021). (In Tib.)

The Ritual of Propitiation and Torma Offering for the Quick-Acting Wisdom Protector SixArmed Mahakala. At: Institute for Mongolian, Buddhist and Tibetan Studies (Siberian Branch of the RAS), Centre of Oriental Manuscripts and Xylographs, Tibetan Collection. Cat. 1055. File no. TT 07694. (In Tib.)

стихиями. Считается, что они проявляют свою активность в полночь. 


\section{Литература}

Андросов 2011 - Андросов В. П. Индо-тибетский буддизм. Энциклопедический словарь. М.: Ориенталия, 2011. 448 с.

Бир 2011 - Бир Р. Энциклопедия тибетских символов и орнаментов. Тибетские буддийские символы. Справочник / пер. с англ. Люки Бубенковой; под общ. ред. А. А. Нариньяни. М.: Ориенталия, 2011. 428 с.

Бир 2013 - Бир Р. Тибетские буддийские символы. Справочник / пер. с англ. Люки Бубенковой; под общ. ред. А. А. Нариньяни. М.: Ориенталия, 2013. 336 с.

Буддийские 2015 - Буддийские ритуальные тексты: по тибетской рукописи XIII в. / факсимиле рукописи; транслитерация А. В. 3орина при участии С. С. Сабруковой; пер. с тибетского, вступ. ст., прим. и приложение А. В. Зорина. М.: Наука; Вост. лит., 2015. $241 \mathrm{c}$.

Бурмистров 2014 - Бурмистров С. Л. Культ и мифология Ганеши (по рукописным материалам из Индийского фонда ИВР РАН) // Письменные памятники Востока. 2014. № 1(20). C. 5-30.

Герасимова 1971 - Герасимова К. М. Памятники эстетической мысли Востока. Тибетский канон пропорций. Трактаты по иконометрии и композиции Амдо, XVIII век. Улан-Удэ: Бурятское кн. изд-во, 1971. 303 с.

Герасимова 1989 - Герасимова К. М. Традиционные верования тибетцев в культовой системе ламаизма. Новосибирск: Наука, Сиб. отд-ние, $1989.320 \mathrm{c}$.

Зорин 2005 - Зорин А. В. Символика культа Махакалы в «Гимне Шестирукому Защитнику» // Вторые Торчиновские чтения: Религиоведение востоковедение (мат-лы науч. конф.) СПб.: Изд-во СПбГУ, 2005. С. 121-125.

Клепиков 1959 - Клепиков С. А. Филиграни и штемпели на бумаге русского и иностранного производства XVII-XX вв. М.: Изд-во Всесоюз. Кн. палаты, 1959. 106 с.

\section{References}

Androsov V. P. Indo-Tibetan Buddhism: Encyclopedic Dictionary. Moscow: Orientalia, 2011. 448 p. (In Russ.)

Bazarov A. A., Namgyal L. A Catalogue of the Tibetan Script Woodblocks of the 'bde chen lhun grub gling' Monastery of Aginsk in Transbaikalia. Journal of Tibetan and Himalayan Studies. 2017. Vol. 2. No. 1-2. Pp. 1-46. (In Eng.)
Лепехова 2020 - Лепехова Е. С. Культ Ганеши и его почитание в японском буддизме // Вестник Института востоковедения РАН. 2020. № 1. C. 33-46. DOI: 10.31696/26187302-2020-1-33-46

Сыртыпова 2003 - Cыртыпова С.-Х. Д. Культ богини-хранительницы Балдан Лхамо в тибетском буддизме (миф, ритуал, письменные источники). М.: Вост. лит., 2003. 238 с.

Терентьев 2004 - Терентьев А. А. Определитель буддийских изображений. СПб.: ФГУИПП «Искусство России», 2004. 302 с.

Цыпкин 2013 - Цылкин Д. О. Штемпельная маркировка образцов и краткие сведения о производителях бумаги // Фотография. Изображение. Документ. 2013. Вып. 4(4). C. 23-31.

Янгутов 2009 - Янгутов Л. Е. Буддийские тексты в Центральной и Восточной Азии // Буддийские тексты в Китае, Тибете, Монголии и Бурятии: сб. ст. Улан-Удэ: Изд-во БНЦ СО PAH, 2009. C. 3-9.

Bazarov, Namgyal 2017 - Bazarov A. A., Namgyal L. A Catalogue of the Tibetan Script Woodblocks of the «bde chen lhun grub gling» Monastery of Aginsk in Transbaikalia // Journal of Tibetan and Himalayan Studies. 2017. Vol. 2. № 1-2. Pp. 1-46.

Bhattacharyya 1985 - Bhattacharyya B. The Indian Buddhist iconography. Calcutta: Ghosh printing house private limited, 1958. $484 \mathrm{p}$.

Jackson 1996 - Jackson D. A History of Tibetan Painting: The Great Tibetan Painters and Their Traditions. Wien: Austrian Academy of Sciences Press, 1996. 456 p.

Nebesky-Wojkowitz 1993 — Nebesky-Wojkowitz de $R$. Oracles and Demons of Tibet: The Cult and Iconography of the Tibetan Protective Deities. Delhi: Rashtra Rachna Printers, 1993. $573 \mathrm{p}$.

Trinle 2002 — Trinle L. (blo bzang 'phrin las). dung dkar tshig mdzod chen mo (Great Tibetological dictionary). Beijing: China Tibetology Publishing House, 2002. 2388 p.

Beer R. The Encyclopedia of Tibetan Symbols and Motifs. L. Bubenkova (transl.), A. Narinyani (ed.). Moscow: Orientalia, 2011. 428 p. (In Russ.)

Beer R. The Handbook of Tibetan Buddhist Symbols. L. Bubenkova (transl.), A. Narinyani (ed.). Moscow: Orientalia, 2013. 336 p. (In Russ.)

Bhattacharyya B. The Indian Buddhist Iconography. Calcutta: Ghosh Printing House Private Limited, 1958. 484 p. (In Eng.) 
Buddhist Ritual Texts: Tibetan Manuscript of the $13^{\text {th }}$ Century. Facsimile. A. Zorin, S. Sabrukova (translit.); A. Zorin (transl., foreword, etc.). Moscow: Nauka; Vostochnaya Literatura, 2015. 241 p. (In Russ. and Tib.)

Burmistrov S. L. The cult and mythology of Ganeśa (based on manuscripts of the Indian Collection of IOM RAS). Pis'mennye pamiatniki Vostoka. 2014. No. 1(20). Pp. 5-30. (In Russ.)

Gerasimova K. M. The Aesthetic Thought of the East and Its Monuments. Tibetan Canon of Proportions. Treatises on Iconometrics and Composition from Amdo, $18^{\text {th }}$ Century. UlanUde: Buryat Book Publ., 1971. 303 p. (In Russ.)

Gerasimova K. M. Traditional Tibetan Beliefs in the Lamaist Religious System. Novosibirsk: Nauka, 1989. 320 p. (In Russ.)

Jackson D. A History of Tibetan Painting: The Great Tibetan Painters and Their Traditions. Wien: Austrian Academy of Sciences Press, 1996. 456 p. (In Eng.)

Klepikov S. A. Filigrees and Stamps on RussiaManufactured and Imported Paper, $17^{\text {th }}-20^{\text {th }}$ Centuries. Moscow: All-Union Book Chamber, 1959. 106 p. (In Russ.)

Lepekhova E. C. Ganeša's cult and his veneration in Japanese Buddhism. Journal of the Institute of Oriental Studies RAS. 2020. No. 1. Pp. 33-46. (In Russ.) DOI: 10.31696/2618-7302-2020-133-46
Nebesky-Wojkowitz de R. Oracles and Demons of Tibet: The Cult and Iconography of the Tibetan Protective Deities. Delhi: Rashtra Rachna Printers, 1993. 573 p. (In Eng.)

Syrtypova S.-Kh. D. The Cult of the Guardian Goddess Palden Lhamo in Tibetan Buddhism. Moscow: Vostochnaya Literatura, 2003. 238 p. (In Russ.)

Terentyev A. A. Buddhist Iconography Identification Guide. St. Petersburg: Iskusstvo Rossii, 2004. 302 p. (In Russ.)

Trinle L. (blo bzang 'phrin las). dung dkar tshig mdzod chen mo (Dungkar Great Tibetological Dictionary). Beijing: China Tibetology Publishing House, 2002. 2388 p. (In Tib.)

Tsypkin D. O. Stamp marking of samples and brief information on paper manufacturers. Photography. Image. Document. 2013. No. 4(4). Pp. 23-31. (In Russ.)

Yangutov L. E. Buddhist texts in Central and East Asia. In: Buddhist Texts in China, Tibet, Mongolia and Buryatia. Collected papers. UlanUde: Buryat Scientific Center (Sib. Branch of RAS), 2009. Pp. 3-9. (In Russ.)

Zorin A. V. Mahakala worship cult's symbolism in The Anthem to the Six-Armed Defender. In: The Second Torchinov Readings. Religious and Oriental Studies. Conference proceedings. St. Petersburg: St. Petersburg State University, 2005. Pp. 121-125. (In Russ.) 